\title{
The Application of Social and Value Marketing in Performance Management \& Human Resource Development: The Case of KAYRA Fashion
}

\author{
Sam Toglaw \\ Department of Marketing, School of Business, The Australian College of Kuwait, Kuwait
}

Received February 10, 2020; Revised April 5, 2020; Accepted April 19, 2020

Copyright $\subseteq 2020$ by authors, all rights reserved. Authors agree that this article remains permanently open access under the terms of the Creative Commons Attribution License 4.0 International License

\begin{abstract}
This study sheds the light on the application of social marketing principles in promoting universal values. It explores the relationship between the promotion of values to workers and the workplace performance. KAYRA was chosen as a case study. It is an international fashion retail company whose core values are tightly aligned with its business strategy. A one-month social marketing campaign was conducted in three branches in the Middle East: Kuwait, Qatar and UAE. It targeted the workers in eight boutiques and focused on the promotion of work-related values such as punctuality, honesty, altruism, cooperation, accountability, diligence and teamwork. Two performance indicators were chosen: number of customers served and sales volume (expressed in the number of units sold in each boutique). Data were compared and analyzed over three months, one month before the campaign and one month during the campaign and one month after the campaign. The results indicated a positive correlation between the promotion of values to sales staff and overall performance at the boutiques. Data analysis revealed an average increase of $20 \%$ in the number of customers served by sales staff who were exposed to the promotion campaign. In addition, the average number of units sold in the participating boutiques increased $5.6 \%$. Although this is a small increase in comparison to the former performance indicator, the study opens up horizons for social marketing of "values" to trigger positive behavior and enhance employees overall performance. The study recommends incorporating planned social marketing campaigns for performance management and human resources development.
\end{abstract}

Keywords Social Marketing, Instrumental and Terminal Values, Intangible Products, Promotion Mix, Perceived Value, Performance Management, Human Resource Management

\section{Introduction}

Social marketing was introduced in 1971 by Philip Kotler and Gerald Zaltman as a new approach to promote social objectives based on the same marketing concepts that promote products and services. They showed how social causes can be advanced successfully by applying principles of marketing in terms of analysis, planning and control. In the marketing terminology, universal values can be considered as intangible social products similar to ideas that are exchanged in political, organizational, educational, leisure, health care and multitude of other settings (Andreason, 1994, Kotler and Lee, 2008). Marketing can be described as the study and management of exchange relationships (Bagozzi, 1975, Hunt, 1976). If a group of workers in a company adopt work-related values such as teamwork, honesty and accountability then it is plausible to say that they are exchanging these values with many benefits such as self-esteem, recognition, peer respect, praise and rewards by the employer. The value of this exchange must be positive, i.e. it is an equation of three variables (Value, Benefit and Cost). Their perceived value is equal to the benefit obtained minus the afforded cost.

In this study we pose the question, how the promotion of values is associated with workplace performance? KAYRA a retail clothing company agreed to examine this relationship and run a social marketing campaign to promote selected values to its workers and sales staff in the State of Kuwait, Qatar and UAE. It has been decided to consider the overall boutique performance in terms of sales and customers served rather than individual performances. 


\section{KAYRA Business Strategy}

KAYRA started its operations in mid-nineties in Istanbul as a fashion designer and a fabricator of stylish women wear. In their business strategy, KAYRA followed a customer-centric approach; they targeted the local, international and Middle Eastern markets with different fashion lines that are customized for these markets.

Its positioning strategy is based on adopting fashionable clothing designs in high quality textile and fabrication. In addition to their standard formal haute couture and casual chic lines, KAYRA was able to introduce complete similar collections of new stylish and modest designs with colorful matching scarves. These creative designs maintained uniqueness and eccentricity. In addition, they appealed to the local culture and values in the Middle East. Their success is based on understanding the cultural mix and customer values in the region

KAYRA is committed to its core values of creativity, excellence and customer care. They welcomed our research proposal to launch a social marketing campaign to promote work values that intersect and synergize with the company core values. They anticipated that sales staff will reflect these values in a favorable behavior by their customers which will enhance their sales performance.

\section{Literature Review}

Values are defined as the basic beliefs that an individual considers to be true. They are enduring and can be stable over time (Arvidsson, 2011). At age of ten, most children have their basic value system firmly in place (Yankelovich, 1994). They become stable over many generations. For example, values taught to American children such as freedom, equality, fairness, achievement and democracy have been passed from one generation to another until now.

According to Rokeach (1979), there are two levels of values, terminal and instrumental. Terminal values are desirable end-states of existence such as happiness, prosperity, salvation and freedom while instrumental values refer to desirable mode of conduct. For example, "ambitious" and "capable" are instrumental values to reach other terminal values such as "comfortable life" and "sense of accomplishment".

The Rokeach Value Survey (RVS) also has a ranking system to examine the importance of values in each culture. For example, honesty and responsibility are very important values in the United States but cheerfulness and politeness are more important in China as they are in the doctrine of Confucianism.

Employers prefer workers who adopt instrumental values that help create a positive work environment and can benefit work performance. Also, workers who have favorable traits and consistently demonstrate good work ethics can be invaluable assets. Personality traits are largely endogenous characteristics, while personal values are learned adaptations strongly influenced by the environment (Olver and Mooradian, 2003). Values such as respect, teamwork, leadership, efficiency, dependability, reliability, responsibility, integrity at work, quality, effectiveness, punctuality, accuracy, diligence, adaptability, self-motivation, keeping promises and professionalism are important for successful organization. However, the nature of business gives higher importance to certain instrumental values over others.

Red Cross and Red Crescent movement promote seven fundamental values that form principles for their workers to follow: humanity, impartiality, neutrality, independence, voluntary service, unity and universality. However, and according to Dilenschneider (2011), when the organization's core values exceed five values, it becomes difficult to communicate and reinforce them among the workforce. Dilenschneider compiled a list of five most important work values that can are linked to the core values of any organization.

Table 1. Dilenschneider most important values

\begin{tabular}{|l|l|}
\hline \multicolumn{2}{|c|}{ Dilenschneider Five Most Important } \\
Work Values
\end{tabular}

Work ethics are based on moral and instrumental values, which guide the right approach, attitude and behavior in a work environment. The habit of following good work ethics is inherent. Workers revealing good work ethics are considered suitable for better positions and more responsibilities. Hence, it is important that workers possess suitable values and traits that can be associated with increased work performance and favorable attitude. Values are very much personal while ethics are very much societal.

\subsection{Values and Performance Management}

Businesses are run by individuals whom their individual and collective performances play an essential role in the overall business success. Coworkers influence each other in a reciprocal manner. However, employee development is a main objective of performance appraisal which typically involves measuring how well an employee is doing against a set of criteria such as personal competencies, behavioral characteristics or achievements. 
Table 2. Covey's, Habits of Highly Effective People

\begin{tabular}{|c|c|}
\hline Dimensions of effectiveness & Habits of highly effective people \\
\hline $\begin{array}{l}\text { Independence } \\
\text { The first three habits surround moving } \\
\text { from dependence to independence } \\
\text { (i.e., self-mastery) }\end{array}$ & $\begin{array}{l}1 \text { - Be Proactive } \\
\text { roles and relationships in life. } \\
2 \text { - Begin with the End in Mind } \\
\text { envision what you want in the future so that you know } \\
\text { concretely what to make a reality. } \\
3 \text { - Put First Things First } \\
\text { A manager must manage his or her own person and } \\
\text { implement activities that aim to reach the second } \\
\text { habit. Covey says that rule two is the mental creation; } \\
\text { rule three is the physical creation }\end{array}$ \\
\hline $\begin{array}{l}\text { Interdependence } \\
\text { The next three habits talk about } \\
\text { working with others }\end{array}$ & $\begin{array}{l}4 \text { - Think Win-Win } \\
\text { Value and respect people by understanding a "win" } \\
\text { for all is ultimately a better long-term resolution } \\
5 \text { - Seek First to Understand, Then to be Understood } \\
\text { Use empathic listening to be genuinely influenced by } \\
\text { a person, which compels them to reciprocate the } \\
\text { listening and take an open mind to being influenced } \\
\text { by you. } \\
\text { 6- Synergize } \\
\text { Combine the strengths of people through positive } \\
\text { teamwork, so as to achieve goals that no one could } \\
\text { have done alone. }\end{array}$ \\
\hline $\begin{array}{l}\text { Continuous Improvements } \\
\text { The final habit is that of continuous } \\
\text { improvement in both the personal and } \\
\text { interpersonal spheres of influence }\end{array}$ & $\begin{array}{l}7 \text { - Sharpen the Saw } \\
\text { Balance and renew your resources, energy, and } \\
\text { health to create a sustainable, long-term, } \\
\text { effective lifestyle. }\end{array}$ \\
\hline
\end{tabular}

Steven Covey (1989) defined the seven habits of highly effective people. These habits have three dimensions that are based on values of independence, interdependence and continuous improvement. All of these habits are important for high performing workers.

Performance appraisal systems are based on subjective and objective criteria that are based on a set of values that trigger favorable behaviors. For example, the value of patience can be correlated to working under stress, and the value of cleanliness is very important for workers in the food, hospitality and medical industries. The subjective criterion covers various elements such as personality, communications skills, self-leadership and initiative. However, the objective performance criterion covers productivity and activity elements such as work quantity, number of units produced, attendance record, etc.

Companies need continuous performance improvement to survive in the increasingly competitive markets. Performance management aims to improve both organizational and workers' individual performance by linking the objectives of each of them. It is an interlocking set of policies and practices which focus on achieving organizational objectives through concentration on individual performance.

\subsection{Social Marketing and the Promotion of Values}

Social marketing combines theories from the marketing and the social sciences. Besides the definition that was coined by Kotler and Zaltman (1971), more recent enhancements of the definition focused on influencing behavior. According to Kotler and Lee (2008), social marketing is "a process that applies marketing principles and techniques to create, communicate, and deliver value in order to influence target audience behaviors that benefit society as well as the target audience". Also, social marketing is defined as "the systematic application of marketing alongside other concepts and techniques to achieve specific behavioural goals, for social or public good" (National Social Marketing Centre, 2006).

Therefore, social marketing campaigns either encourage or discourage a behavior. Examples are campaigns that address caring for the environment, wearing seat belts, quitting smoking, avoiding drink driving, etc. (Marketing-Schools, 2012).

On the other hand, values as "social products" are similar to ideas, they undergo an exchange process between two different parties. One party promotes the idea and the other one accepts or embraces it. Fine (1981) indicated that the process of publicizing ideas is in fact a 
marketing process. Similarly, values that are useful in the workplace can be promoted in a marketing campaign and exchanged with worker's personal benefits and favorable behaviors that can be rewarding to the workers. The adoption of promoted values will be faster if they come aligned with worker's personal values.

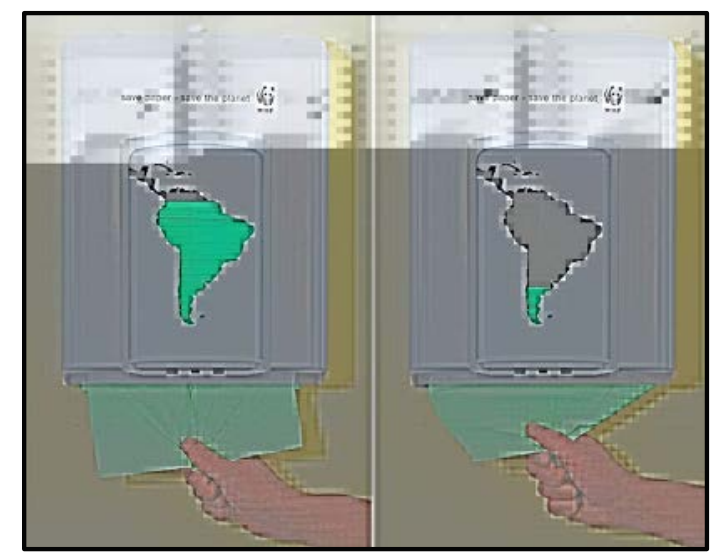

Figure 1. Social marketing campaign Save Paper... Save the Planet

\subsection{How Can Social Marketing Be Applied to Promote Instrumental Values?}

Marketing of values require a customized marketing mix and an effective promotion mix in order to communicate the benefits of exchange for the targeted workers. Hence, it is understood that the marketing mix maximizes the perceived value of the exchange process, while the promotion mix communicates it to the target audience.

Since values are considered social and intangible products, then the marketing mix of intangible products includes the traditional 4Ps plus three more Ps (People, Process and Physical evidence).

The traditional 4Ps include creating an appealing "Product" i.e. the promoted values that will bring a package of benefits for the workers. The "Price" in the marketing mix represents the cost that worker must pay in order to progress the exchange process. The "Place" indicates that the offering is done in the right place and time. In addition, it is delivered in a suitable channel to the target audience, for example face to face or through digital media. Finally, "Promotion" includes the promotion mix that is designed to promote the product (instrumental values) the target audience. It includes tactics and tools that can communicate the benefits of adopting such values and reflecting them in various positive or favorable behaviors.

The extra three Ps can be explained as follows: $\mathrm{P}$ for "People" who are promoting the social products to the target audience, then the second $\mathrm{P}$ for the "Process" of presenting and progressing the exchange to reach mutual benefits for both the workers and the company. The last $\mathrm{P}$ is for "Physical evidence" such as features, uniforms, tags, policies, etc approved by the company to reflect seriousness and commitment of the company's management in adopting and promoting the promoted values.

Aligning the promoted values with workers' personal values and the company's core values is very appealing to reach synergy and effectiveness. Companies give special attention to their core values because they are foundational elements for establishing meaningful mission, vision and strategic goals. They also contribute to the company's competitive advantage and brand differentiation (Gligorea, 2016).

\section{Methods}

The study has two main objectives. The first one is to shed the light on social marketing and present its applications for the social good and the wellbeing of organizations. Under this objective we show how a marketing campaign can be designed to promote values. The second objective is to explore the relationship between the promotion of values in a company and the workplace performance. In our discussion, we mean by "values" the instrumental values that describe the desirable mode of conduct.

An internal social marketing campaign was launched in a fashion retail company, targeting workers and sales staff in different boutique or showrooms. KAYRA was chosen as a case study. A quantitative approach was used to measure the examined performance indicators. In addition, qualitative tools such as researcher's personal observation and short interviews with line managers and workers were used to form a better understanding about workers' behaviors and personal experience following the promotion campaign.

\subsection{Sample}

Table 3. Employees exposed to the campaign

\begin{tabular}{|l|c|}
\hline \multicolumn{1}{|c|}{$\begin{array}{c}\text { KAYRA } \\
\text { Branches }\end{array}$} & $\begin{array}{c}\text { Number of } \\
\text { Employees }\end{array}$ \\
\hline $\begin{array}{l}\text { KAYRA } \\
\text { Head office \& Operations }\end{array}$ & 8 \\
\hline Kuwait Boutiques & 6 \\
\hline Muhallab Mall & 3 \\
\hline Othman Mall & 4 \\
\hline Kuwait Magic Mall & 3 \\
\hline Bayraq Mall & 7 \\
\hline Qatar Boutiques & 7 \\
\hline Lagoona Mall & 4 \\
\hline Hayat Plaza & 7 \\
\hline UAE Boutiques & $\mathbf{4 9}$ \\
\hline Bon Marche & \\
\hline $\begin{array}{l}\text { Corniche Abu Dhabi } \\
\text { Holywood Magic }\end{array}$ & \\
\hline TOTAL & \\
\hline
\end{tabular}


The sample was taken from the employees of KAYRA in the Gulf operations. It included the workers of KAYRA in eight boutiques distributed in three countries: Kuwait, Qatar and UAE. Although the workers in the regional head office were exposed to the campaign, only sales staff in eight boutiques was included in the data analysis. A total of forty nine employees were introduced to the campaign before it started.

\subsection{The Marketing Campaign}

One-month promotion campaign was run in three countries which focused on promoting instrumental values such as punctuality, honesty, altruism, cooperation, accountability, diligence, teamwork, proactive behavior, accommodation and service. The campaign used integrated marketing communication approach (IMC) in order to ensure that all tools were emphasizing the same message.

The campaign used integrated marketing communication approach (IMC) in order to ensure that all tools were emphasizing the same message. The promotion mix included internal advertising of the selected values on wall mounted screens and roll up banners. Operation managers were asked to emphasize company core values and the promoted work values in the beginning of each weekly meeting with the staff. In addition, external speakers were invited to motivate workers implement these values in their transactions with customers.

Digital marketing was also incorporated in the IMC including the company's website, social media as well as email communications which included proverbs and motivational quotes by famous people, messages from line managers, HR manager and CEO of the company.

\section{Results}

Two performance indicators were chosen: number of customers served and sales volume. For tactical reasons and issues related to the market competition, KAYRA did not prefer to release the sales figures for each boutique. Instead, the management agreed to disclose the number of units sold in each boutique. In order to establish a base for comparison, it has been decided to compare figures before, during and after the campaign.

Quantitative data was easily analyzed because it was a straight forward task that included counting the number of customers served by each salesman and number of units sold within a three month period. This included one month before the campaign and one month during the comparison and one month after the campaign.

Usually, fashion visual merchandise is set for the whole collection every season and accordingly companies change their sales promotions. For example, the winter collection is totally different from the summer collection. Therefore, in order to eliminate interference of other variables on the results, the three-month period was chosen under one season and under one sales promotion. It is important to mention that after running the social marketing campaign under the above controlled variables, a UAE sales campaign coincided with our campaign. Data was treated to cater for this interference as explained below.

Table 4. Number of customers served

\begin{tabular}{|l|l|l|l|l|l|}
\hline C.S: Customers served & $\begin{array}{c}\text { Oct } \\
\text { C.S }\end{array}$ & $\begin{array}{l}\text { Nov } \\
\text { C.S }\end{array}$ & $\begin{array}{l}\text { Dec } \\
\text { C.S }\end{array}$ & $\begin{array}{l}\text { \% change } \\
\text { Nov }\end{array}$ & $\begin{array}{c}\text { \% change } \\
\text { Dec }\end{array}$ \\
\hline Kuwait Boutiques & & & & & \\
\hline Muhallab Mall & 1111 & 1132 & 1130 & $+1.89 \%$ & $+1.7 \%$ \\
\hline Othman Mall & 691 & 774 & 782 & $+12 \%$ & $+13.1 \%$ \\
\hline Kuwait Magic Mall & 984 & 1014 & 1233 & $+3 \%$ & $+25 \%$ \\
\hline Bayraq Mall & 602 & 782 & 804 & $+29.9 \%$ & $+33.7 \%$ \\
\hline Qatar Boutiques & & & & & \\
\hline Lagoona Mall & 682 & 760 & 874 & $+11.5 \%$ & $+28.1 \%$ \\
\hline Hayat Plaza & 1108 & 1342 & 1339 & $+21.1 \%$ & $+19.9 \%$ \\
\hline UAE Boutiques & & & & Ave $13.2 \%$ & Ave $20.25 \%$ \\
\hline Abu Dhabi & 256 & 574 & 1189 & $224 \%$ & $464 \%$ \\
\hline Dubai & 534 & 674 & 1353 & $26.2 \%$ & $253 \%$ \\
\hline
\end{tabular}


Table 5. Number of units sold

\begin{tabular}{|l|l|l|l|l|l|}
\hline U.S: Units sold & $\begin{array}{l}\text { Oct } \\
\text { U.S }\end{array}$ & $\begin{array}{l}\text { Nov } \\
\text { U.S }\end{array}$ & $\begin{array}{l}\text { Dec } \\
\text { U.S }\end{array}$ & $\begin{array}{l}\text { \% change } \\
\text { Nov }\end{array}$ & $\begin{array}{c}\text { \% change } \\
\text { Dec }\end{array}$ \\
\hline Kuwait Boutiques & & & & & \\
\hline Muhallab Mall & 778 & 816 & 835 & $+4.8 \%$ & $+7.3 \%$ \\
\hline Othman Mall & 501 & 504 & 526 & $+0.05 \%$ & $+4.9 \%$ \\
\hline Kuwait Magic Mall & 855 & 850 & 889 & $-0.058 \%$ & $+3.97 \%$ \\
\hline Bayraq Mall & 440 & 470 & 482 & $+6.8 \%$ & $+9.5 \%$ \\
\hline Qatar Boutiques & & & & & \\
\hline Lagoona Mall & 480 & 497 & 496 & $+3.5 \%$ & $+3 \%$ \\
\hline Hayat Plaza & 792 & 839 & 831 & $+5.9 \%$ & $+4.9 \%$ \\
\hline UAE Boutiques & & & & $A v e 3.5 \%$ & Ave $5.6 \%$ \\
\hline Bon Marche & 190 & 410 & 901 & $215 \%$ & $474 \%$ \\
\hline $\begin{array}{l}\text { Corniche Abu Dhabi } \\
\text { Holywood Magic }\end{array}$ & 390 & 499 & 908 & $27.9 \%$ & $233 \%$ \\
\hline
\end{tabular}

\section{Output of Interviews and Personal Observations}

Boutiques in Kuwait were paid weekly visits in order to stay close to the sales persons. Four short interviews with line managers were conducted to capture their opinions and to follow up the progress of the campaign. Line managers were asked about their opinions and personal evaluation of the sales staff response to the campaign. Several positive feedbacks were collected. The sales manager of Bayraq boutique stated: "I was happy to see Issam [one of the salesmen] staying half an hour after the boutique closing time to serve the last customer entered the boutique. This is a higher level of perseverance that I see as a result of the values promotion campaign".

Also, Kuwait operations' manager stated:" I give higher priory to customer service and self-initiatives to find what the customer really wants. Now and after nearly two weeks from the start of the campaign, I can tell we are scoring a higher level of customer service than before".

In addition, six short interviews were conducted with sales workers. One of the salesmen of the boutiques stated: "I wish this campaign stays longer...this campaign made me live these values". Another one stated: "This is a very useful campaign. I wish the company did it many years ago. I recommend they give us training to emphasize the application of these values practically with our customers".

The qualitative data obtained from interviews and personal observations indicated that line managers and sales staff liked the campaign as it came in line with and supporting their individual work targets. Sales staff reflected favorable work behaviors and positive behavior with customers.

\section{Discussion}

By looking at the numbers of "customers served" shown in Table 4, and number of units sold shown in Table 6, we see an increase in these numbers during November and December. However, the increase in UAE numbers is dramatically high. That was due to a sales campaign that took place only in UAE but not in Kuwait and Qatar. Although the UAE branch was subject to the campaign of value promotion during November, the figures of the performance indicators are not considered because of the interference of sales campaign which increased the sales volume.

On the other hand, when looking at Table 4, the figures of "customers served" for Kuwait and Qatar boutiques reflect an average increase of $13.2 \%$ during November which is the month of campaign and around $20.25 \%$ increase after the campaign in the month of December. This increase can be referred to the carried out effect of the promotional campaign which showed higher results after thirty-day exposure to the marketing communications campaign. Workers are motivated to serve more customers by emphasizing service and proactive behavior.

The number of units sold is shown in Table 5. For Kuwait and Qatar branches, we see an average increase of $3.5 \%$ during November the month of campaign and around $5.6 \%$ after the campaign (in the month of December). This increase can be referred to the carried out effect of the promotional campaign which showed higher results after thirty-day exposure to the promotion campaign.

Some boutiques showed no increase or showed negligible increase in the units sold during the month of the campaign such as the ones in Othman Mall and Kuwait Magic Mall but the number of units sold after the campaign has slightly increased after the campaign due to the carried out effect. Also, the individual differences in sales staff 
capabilities and experiences will contribute to boutique performance figures. The response of the workers to promotional campaign can also be influenced by other factors such as age, gender, culture and ethnic group.

\section{Conclusions}

This study sheds the light on the application of social marketing campaigns in the promotion of work related values and how it influences the workplace performance. However, due to the scarcity of literature in this field, the study is limited in its scope and the examined variables. It is an eye opener on the applicability and implications of social marketing in managing the performance of human resources.

First of all, values are treated as "intangible products" and the underlying marketing principles maximize the worker's "perceived value" of adopting a "universal or work-related value" and reflecting it in a "positive work behavior "such as teamwork, productive cooperation, synergy, proactive behavior and customer service.

Marketing values require more persuasive tools that can influence the workers' inner minds and subsequently their behavior. These can be provided by exploring suitable marketing communication tools. The adoption of new values by workers can be substantiated when it is reflected in a behavioral change.

It is observed that the one-month campaign generated a carried out effect which was more noticeable in the following month. This is a very inspiring finding for companies to invest in organizing round the year campaigns to promote favorable values and positive work behaviors. For example, courier companies compete with each other to fulfill their promises to their customers in providing the best delivery time and most reliable service. Social marketing campaigns can focus on values that support their promises such as responsiveness, accuracy and duty of care. Coworkers will add value to each other by reciprocal positive interaction.

Human Resource Development "HRD" indicates the improvement in productivity and competitiveness of an organization by focusing on developing the skills of the workforce for economic survival. Companies can spend on social marketing campaigns that focus on the promotion of values in order to maintain high performance.

Future studies can involve a larger sample and can be longitudinal over a longer period of time in order to study the effect of the campaign over a longer period of time and see the changes in workers behavior and their performance. Other variables can be measures such as customers' satisfaction, positive work behavior and changes in individual performances.

Performance appraisal systems can be based on subjective and objective criteria. Future studies can consider more subjective criteria that measure the change in personality, loyalty, dependability, communications skills, ability to work under stress and self-leadership.

\section{Acknowledgements}

I am grateful to the executive management of KAYRA and their regional and line managers for their cooperation and support to the promotion campaign. Their commitment was a source of motivation to us and to the sales staff to progress the campaign successfully.

\section{REFERENCES}

[1] Ambler, T. (2001) "Value-based marketing: Marketing strategies for corporate growth and shareholder value", Journal of Brand Management, 8(6) pp 463-466

[2] Andreasen, A. R. (1994), "Social marketing: its definition and domain”, Journal of Public Policy \& Marketing, 13(1), pp. 108-114

[3] Arvidsson, A. (2011) 'Ethics and value in customer co-production”, Marketing Theory, 11(3), pp 261-278

[4] Bagozzi, R. (1975) "Marketing as Exchange", Journal of Marketing, 39 (4) pp 32-39

[5] Caruana, R. (2007a) 'Morality and consumption: Towards a multidisciplinary perspective', Journal of Marketing Management, 23(3-4), pp 207-225

[6] Covey, S. “ The seven habits of highly effective people” Viewed 12 July 2018, (http://en.wikipedia.org/wiki/The_S even_Habits_of_Highly_Effective_People

[7] Dilenschneide (2011), Viewed 3 Aug 2018(20https://www. dilenschneider.com/

[8] Feather, N. \& Peay, E. (1975). "The structure of terminal and instrumental values: Dimensions and clusters” Australian Journal of Psychology, 27(2), pp 151-164

[9] Fine, S. (1981), "The marketing of ideas and social issues", Praeger Publishers, New York

[10] Gligorea, R (2016) The importance of core values in building

a powerful business, viewed 1Sep 2018https://www.perfor mancemagazine.org/importance-core-values-building-pow erful-business/

[11] Hunt, S. (1976). "The Nature and Scope of Marketing", Journal of Marketing. 40(3), pp 17-28.

[12] Keller, K. L. (1998), "Branding perspectives on social marketing”, Advances in Consumer Research, 25 (2), pp 299-302.

[13] Kotler, P., Zaltman, G. (1971), “Social Marketing: An Approach to Planned Social Change”, Journal of Marketing, 1971, Vol. 35, pp. 3-12. 
[14] Kotler, P. and Lee, N. (2008), Social Marketing: Influencing Behaviors for Good, $3^{\text {rd }}$ edition, Thousand Oaks, CA: Sage.

[15] Lichtenstein, S, Lichtenstein, G, Higgs M, (2017) "Personal values at work: A mixed-methods study of executives' strategic decision-making”, Journal of General Management, 43 (1), pp 3-14

[16] Lockett, J. (1992), Effective Performance Management: A Strategic guide to getting the best from people, Kogan Page, London

[17] Marketing Schools (2012), Social Marketing. Viewed 5 July 2018 https://www.marketing-schools.org/types-of- marketi ng/social-marketing.html

[18] Nanda, A. (2015) “Social Marketing: A Literature Review”, International Journal of Science and Research, 4 (9) pp 697-702

[19] Olver, J., Mooradian, T.(2003) "Personality traits and personal values: A conceptual and empirical integration”, Personality and Individual Differences, 35(1):109-125

[20] Rokeach, M.(1979). H. E. Symposium on Motivation (27). Lincoln: Univ of Nebraska Press. 